\title{
Pengembangan Modul Kimia Muatan Lokal Valid dan Praktis Tentang Pakan Ampas Tahu Terfermentasi untuk Pertumbuhan Ikan Patin Berbasis STEM-PBL
}

\author{
Sari Marlisyah ${ }^{1)}, \mathrm{K}_{\text {Anom }} \mathrm{W}^{1)}$, Made Sukaryawan ${ }^{1)}$ \\ 1) Pendidikan Kimia Universitas Sriwijaya \\ sarimarlisya@gmail.com
}

\begin{abstract}
This research is a development research that aims to produce a local integrated chemical module that integrates STEM Problem Based Learning which is valid and practical. The development model used was ADDIE (Analysis, Design, Development, Implementation, Evaluation) and evaluated by Tessmer formative method. Tessmer formative evaluation stages in this study include evaluation, expert review, one-to-one and small group. The results of the expert review stage obtained the average score of the validity of 0.76 Aiken scale with the category is very valid. For the final score the practicality is obtained from one-to-one test of 0.67 Aiken scale (practical) and small group 0.75 Aiken scale (practical). Based on the evaluation results show that the resulting module has met the valid and practical criteria. It is suggested that this module can be used as an alternative material for entrepreneurship subject.
\end{abstract}

Keywords: Development Research, Chemical Modules Local Content, STEM Problem Based Learning, Entrepreneurship

This is an open access article distributed under the Creative Commons 4.0 Attribution License, which permits unrestricted use, distribution, and reproduction in any medium, provided the original work is properly cited. $\odot 2018$ by author and Universitas Negeri Padang.

\section{PENDAHULUAN}

Tahun 2013 Kementerian Pendidikan dan Kebudayaan mengubah kurikulum mulai dari pendidikan dasar sampai pendidikan tinggi. Sesuai dengan undang-undang No 12 tahun 2012, bahwa perguruan tinggi memiliki otonomi dalam penyusunan kurikulum, namun pada pelaksanaannya diperlukan rambu-rambu yang sama agar dapat mencapai hasil yang optimal. Perubahan pada proses pembelajaran menjadi pen ting dan akan menciptakan iklim akademik yang akan meningkatkan kompetensi mahasiswa baik hardskills maupun softskills.

Mata kuliah kewirausahaan merupakan pelajaran yang membentuk karakter wirausaha atau minimal mahasiswa menambah pengetahuan mahasiswa mengenai seluk-beluk bisnis baik dari sisi soft skill maupun hard skill sehingga mahasiswa mampu memanfaatkan peluang peluang yang ada di sekitarnya dalam menciptakan usaha sendiri setelah lulus maupun saat masih kuliah (Santoso, 2013).

Pada kurikulum 2013 mata kuliah kewira usahaan sudah dipadukan menjadi prakarya dan kewirausahaan, dimana dalam berwirausaha peserta didik harus bisa menciptakan produk hasil karyanya untuk bisa dijadikan peluang usaha. Indonesia yang dikenal dengan kuliner nya yang beraneka ragam dan dengan makanan khas daerah yang terkenal dan diminati banyak masyarakat. Daerah-daerah di Indonesia banyak sabagai tempat wisata yang banyak dikunjungi wisatawan dari antar kota dan luar negeri, maka dalam usaha kuliner atau makanan khas daerah adalah peluang yang sangat besar untuk berwirausaha.

Ikan patin merupakan jenis ikan konsumsi air tawar asli Indonesia yang tersebar di sebagian wilayah nuasantara. Ikan patin memiliki kandungan kalori dan protein yang cukup tinggi, rasa dagingnya khas, enak dan gurih sehingga digemari oleh masyarakat. Ikan patin dinilai lebih aman untuk kesehatan karena kadar kolestrolnya rendah dibandingkan dengan da ging hewan ternak. Selain itu ikan patin memiliki beberapa kelebihan lain, yaitu ukuran per individunya besar dan di alam panjangnya bisa mencapai 120 $\mathrm{cm}$ (Susanto dan Amri, 2002). Harga jual ikan patin cukup tinggi dan sebagai komoditi yang memiliki prospek cerah untuk dibudidayakan. Kendala yang sering dijumpai dalam budidaya ikan patin adalah pakan. Pada pembudidayaan ikan patin untuk satu keramba apung berisi 300500 ikan yang bisa menghabiskan 1 karung pelet pabrik seharga Rp 300.000/hari. Dengan pengembang an pakan ikan mandiri, 
penghematan biaya produksi budidaya ikan sangat besar dengan pembuatan pakan alternatif (Kordi, 2005).

Ampas tahu yang merupakan limbah industri tahu memiliki kelebihan, yaitu kandungan protein yang cukup tinggi. Menurut Ali dkk (2010) ampas tahu dapat digunakan sebagai sumber protein serta mengandung unsurunsur mineral mikro maupun makro yaitu untuk mikro; Fe 200-500 ppm, Mn 30-100 ppm, Cu 515 ppm, Co kurang dari 1 ppm, Zn lebih dari 50 ppm. Ampas tahu dalam keadaan segar berkadar air sekitar $84,5 \%$ dari bobotnya. Kadar air yang tinggi dapat menyebabkan umur simpannya pendek. Ampas tahu basah tidak tahan di sampan dan akan cepat menjadi asam dan busuk selama 2-3 hari, sehingga ternak tidak menyukainya lagi. Ampas tahu kering mengandung air 10,0-15,5\% sehingga umur simpanannya lebih lama dibandingkan dengan ampas tahu segar.

Untuk mendukung hal tersebut perlu dikembangkan bahan ajar yang lebih spesifik untuk meningkatkan minat berwirausaha peserta didik. Bahan ajar berupa modul dirancang untuk membantu guru dalam memberikan pengalaman belajar yang melibatkan proses mental dan fisik melalui interaksi antar peserta didik, peserta didik dengan guru, lingkungan, dan sumber belajar lainnya dalam rangka pencapaian kompetensi yang diharapkan. Pengalaman belajar yang dimaksud dapat terwujud melalui penggunaan pendekatan pembelajaran yang berpusat pada peserta didik, yang memuat kecakapan hidup yang perlu mereka kuasai agar mampu menciptakan usaha sendiri setelah lulus maupun pada saat masih kuliah.

Modul ini terintegrasi STEM Problem Based Learning yang diperlukan oleh mahasiswa untuk mengembangkan budidaya ikan patin. STEM dan Problem Based Learning saling berkaitan antara satu dan lainnya. Menurut Pratiwi dkk (2014) modul yang terintegrasi pada STEM dan PBL akan sangat membantu mahasiswa untuk berpikir kritis, mampu memecahkan masalah, kerjasama tim dan meningkatkan kemampuan belajar mahasiswa. Selain itu tujuan lain dari STEM ialah mampu mengembangkan diri, memiliki kemampuan sosial dan budaya, produktif dan bertanggung jawab. Untuk memenuhi harapan tersebut, maka pendidikan STEM dapat diterapkan di sekolah atau universitas di Indonesia agar Indonesia mampu menghasilkan tenaga kerja yang kompetitif dengan negara-negara maju yang memimpin perekonomian global.

\section{METODE PENELITIAN}

Prosedur penelitian yang dilakukan sesuai dengan model pengembangan. Tahapan-tahapan nya ialah :

\section{Analysis (Analisis)}

Pada tahap ini peneliti melakukan 3 analisis yaitu analisis karakteristik mahasiswa, analisis kebutuhan, dan analisis kurikulum. Analisis karakteristik dan kebutuhan dirasakan oleh peneliti sendiri sebagai mahasiswa. Sedangkan analisis kurikulum menyesuaikan tujuan pembelajaran mata kuliah kewirausahaan. Pada mata kuliah kewirausahaan sudah ada teoriteori untuk berwirausaha namun belum dipraktikkan lagi. Modul ini juga sebagai contoh desain untuk berwirausah. Dengan adanya modul ini diharapkan mahasiswa dapat menerapkan desain ini dengan berwirausaha yang lain.

\section{Design (Desain)}

Dalam tahap desain ini, penyusunan draft berdasarkan komponen-komponen da ri modul. Menurut Parmin dan Peniati (2012) komponen modul yaitu mencakup pendahuluan, latar belakang, kegiatan belajar yang mengandung uraian isi pembelajaran, rangkuman, tes, kunci jawaban, dan umpan balik, serta daftar pustaka. Desain modul difokuskan pada aspek konten, pedagogik dan tampilan

\section{Development (Pengembangan)}

Pada tahap ini dilakukan pengem bangan terhadap modul yang telah disu sun dan dirancang sebelumnya dan dilakukan evaluasi formatif Tessmer. Tujuannya adalah untuk kepentingan revisi. Berikut penjelasan dari masing-masing tahapan evaluasi formatif rancangan Tessmer dapat dijelaskan sebagai berikut:

\section{a. Self-Evaluation}

Pada tahap ini dilakukan penilaian oleh peneliti terhadap Spesifik prototype dengan cara pengecekan sendiri tentang konten, pedagogik dan tampilan.

\section{b. Expert Review}

Pada tahap ini, Spesifik Prototype yang telah dikembangkan di validasi oleh para ahli atau pakar yaitu dilakukan validasi materi, validasi desain dan validasi pedagogik oleh dua 
dosen ahli materi, dua dosen ahli desain dan dua dosen ahli pedagogik.

\section{c. One-To-One}

Pada tahap ini dilakukan uji coba kepada 3 orang mahasiswa. Ketiga mahasiswa yang terpilih diminta untuk mempelajari modul (Spesifik Prototype) yang telah dikembangkan lalu mahasiswa diwawancarai untuk menilai kepraktisan mo dul. Hasil tanggapan dan saran mahasiswa dijadikan sebagai acuan untuk melakukan revisi. Setelah tahap Expert Review dan One-To-One dilakukan, maka modul ini direvisi dan menghasilkan Prototype 1 yang nanti akan diujicobakan pada kelompok kecil.

\section{d. Small Group}

Pada tahap ini dilakukan uji coba kepada kelompok kecil berjumlah 9 mahasiswa. Mahasiswa diminta untuk mempelajari modul yang terintegrasi STEM-PBL kemudian maha siswa diwawancari untuk menilai kepraktisan modul yang telah dikembangkan. Hasil dari tanggapan dan saran dijadikan acuan untuk melakukan revisi dan hasil revisinya yang disebut prototype 2 .

Uji validasi dilakukan oleh dua ahli pedagogik, dua ahli materi, dan dua ahli desain dengan kesepakatan atau konsistensi internal yaitu menggunakan Formula Aiken ditampilkan dalam Tabel 1 berikut.

$$
\mathrm{V}=\sum \mathrm{s} /[\mathrm{n}(\mathrm{c}-1)
$$

\section{Keterangan:}

$\mathrm{S}=\mathrm{r}-\mathrm{lo}$

lo = Angka penilaian validitas yang terendah (dalam hal ini adalah 1)

c = Angka penilaian validitas yang tertinggi (dalam hal ini adalah 4)

$r$ = Angka yang diberikan oleh penilai

$\mathrm{n}$ = Jumlah Expert
Tabel 1. Kriteria Validasi Aiken

\begin{tabular}{|l|l|l|}
\hline \multicolumn{1}{|c|}{ Nilai $\mathrm{K}$} & \multicolumn{1}{|c|}{$\begin{array}{c}\text { Kekuatan } \\
\text { Kesepakatan }\end{array}$} & \multicolumn{1}{|c|}{ Kategori } \\
\hline $0-0,20$ & Sangat Rendah & $\begin{array}{l}\text { Sangat tidak } \\
\text { valid }\end{array}$ \\
\hline $0,21-0,40$ & Rendah & Tidak valid \\
\hline $0,41-0,60$ & Cukup Tinggi & $\begin{array}{l}\text { Kurang } \\
\text { valid }\end{array}$ \\
\hline $0,61-0,80$ & Tinggi & Valid \\
\hline $0,81-1,00$ & Sangat Tinggi & Sangat valid \\
\hline
\end{tabular}

Analissis data wawancara dalam penelitian ini dilakukan dengan menggunakan statistik Aiken untuk mencari kepraktisan modul kimia muatan lokal terintegrasi STEM Problem Based Learning tentang pengaruh pakan ampas tahu terfermentasi terhadap pertumbuhan ikan patin. Data diperoleh dari angket yang diberikan ke mahasiswa sebagai responden dalam uji coba angket dalam skala likert 1 sampai 4. Modul dikatakan praktis apabila nilai Aiken lebih dari 0,60 .

$$
\mathrm{V}=\sum \frac{\mathrm{S}}{[\mathrm{n}(\mathrm{c}-1)]}
$$

Keterangan:

$\mathrm{S}=\mathrm{r}-\mathrm{lo}$

lo $=$ Angka penilaian validitas yang terendah (dalam hal ini adalah 1)

c = Angka penilaian validitas yang tertinggi (dalam hal ini adalah 4)

$\mathrm{r}=$ Angka yang diberikan oleh penilai

$\mathrm{n}=$ Jumlah Expert

Pada persamaan, $\mathrm{r}$ adalah koefisien korelasi. Nilai koefisien korelasi dapat diperhatikan pada Tabel 2

Tabel 2. Interpretasi Koefisien Nilai $r$

\begin{tabular}{|c|l|}
\hline Interval Koefisien & \multicolumn{1}{|c|}{ Tingkat Hubungan } \\
\hline $0,80-1,00$ & Sangat praktis \\
\hline $0,60-0,799$ & Praktis \\
\hline $0,40-0,599$ & Cukup praktis \\
\hline $0,20-0,399$ & Tidak praktis \\
\hline $0,00-0,199$ & $\begin{array}{l}\text { Sangat tidak } \\
\text { praktis }\end{array}$ \\
\hline
\end{tabular}




\section{Diagram Alir Penelitian Pengembangan}

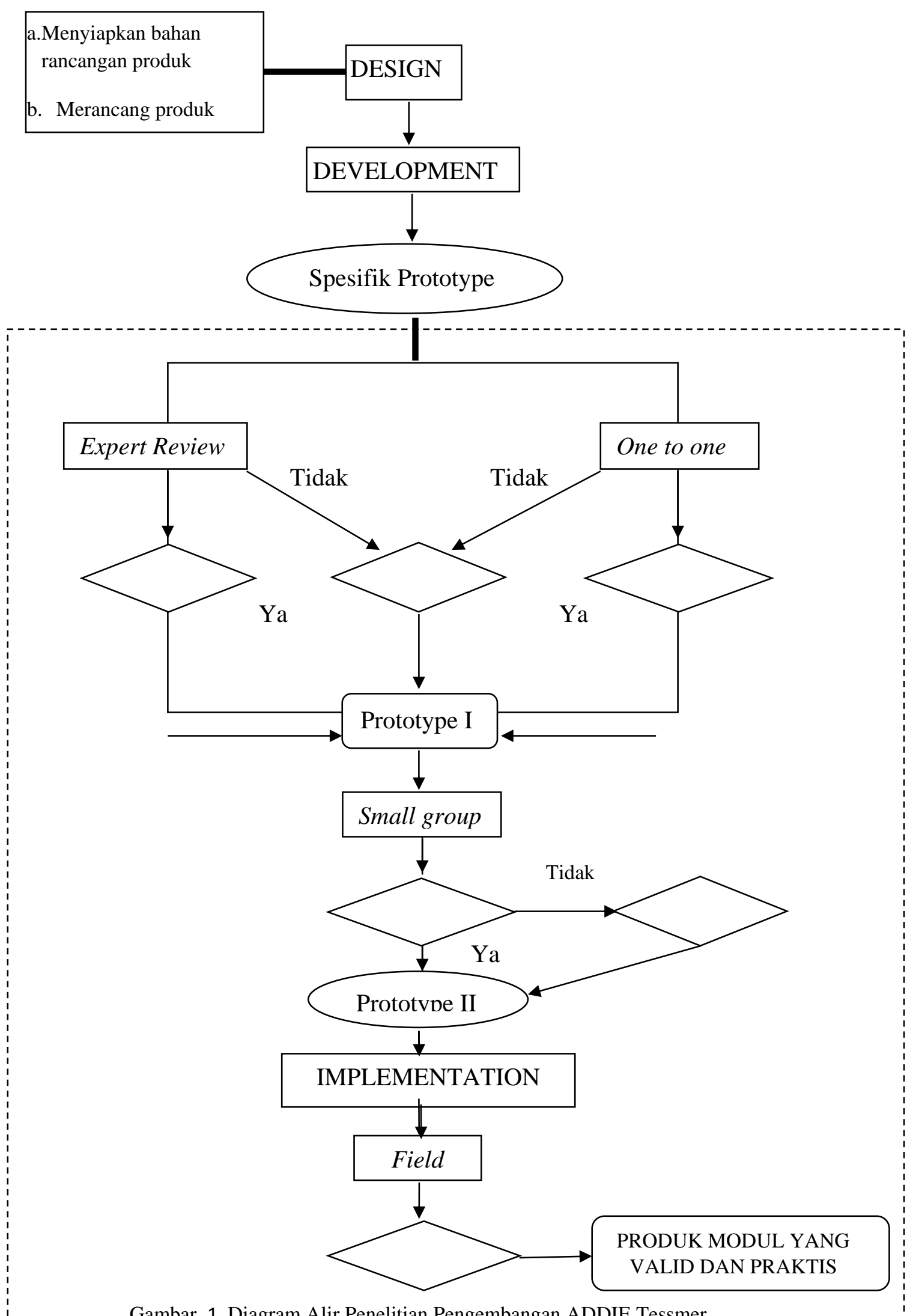




\section{HASIL DAN PEMBAHASAN}

Pada penelitian ini menghasilkan produk berupa modul kimia muatan lokal. Model pengembangan yang digunakan dalam penelitian ini merupakan adaptasi dari model pengembangan ADDIE yang telah dimodifikasi.

\section{Hasil Tahap Analisis}

Tahap Analisis ini terdiri dari analisis karakteristik mahasiswa, analisis kebutuhan, dan analisis kurikulum. Analisis karakteristik dan kebutuhan dirasakan oleh peneliti sendiri sebagai mahasiswa. Berdasarkan dari pengalaman yang dirasakan peneliti, dalam proses belajar mahasiswa masih belum menggunakan modul dan bahan ajar untuk mata kuliah kewirausahan.

Analisis kurikulum menyesuaikan tujuan pembelajaran mata kuliah kewirausahaan, pada mata kuliah kewirausahaan sudah ada teori-teori untuk berwirausaha namun belum dipraktikkan. Modul ini juga sebagai contoh desain untuk berwirausaha, dengan adanya modul ini diharapkan mahasiswa dapat menerapkan desain ini dengan berwirausaha yang lain.

Pada tahap analisis didapat hasil bahwa perlu dikembangkan lagi bahan ajar baru untuk mendukung mahasiswa belajar mandiri baik di kelas maupun di rumah. Selain itu bahan ajar dikembangkan terintegrasi STEM Problem Based Learning sebagai alternatif untuk membantu kegiatan pembelajaran di kelas.

\section{Hasil Tahap Perancangan}

Tahap perancangan ini dilakukan dengan cara mengembangkan produk awal berupa mo dul menggunakan pendekatan STEM Problem Based Learning. Dalam proses perancangan mengacu pada produksi spesifik prototype. Pada tahap ini, peneliti mulai mendesain bahan ajar berbentuk modul dan menyusun bagian-bagian dalam bahan ajar tersebut seperti halaman judul, kata pengantar, daftar isi, deskripsi modul, kompetensi pencapaian, tujuan pembelajaran, materi, lembar evaluasi dan daftar pustaka. Dalam pro ses mendesain, diperhatikan dari segi bahasa, konten (isi materi sesuai dengan tujuan pembelajaran), dan konstruk (materi dan instrumen sesuai dengan pembelajaran berbasis masalah). Rancangan modul terlebih dahulu ke tahap self-evaluation sebagai bahan pertimbangan untuk melanjutkan tahapan menghasilkan produk spesifik prototype. Dalam proses self-evaluation dilakukan dengan cara memeriksa secara berulang produk yang telah jadi, selain itu dilakukan pula konsultasi dengan dosen pembimbing guna meminimalisir kesalahan.

\section{Hasil Tahap Pengembangan}

Dari hasil spesifik prototype ini, produk berupa modul dikembangkan untuk menguji kevalidan dan kepraktisan. Proses yang dilakukan yaitu expert review, uji one to one, dan uji small group.

\section{a. Expert Review (Evaluasi Ahli)}

Produk modul menggunakan pendekatan STEM Problem Based Learning yang merupakan hasil spesifik prototype selanjutnya divalidasi oleh 6 orang ahli, yakni dua ahli pedagogik, dua ahli materi dan dua ahli desain. Hasil validasi yang diperoleh dari masing - masing validator yaitu: validasi pedagogik skor yang diperoleh sebesar 12.01 skala aiken dengan rata - rata 0.75 skala Aiken, validasi materi skor yang diperoleh sebesar 6,99 skala aiken dengan rata - rata 0,77 skala Aiken, validasi desain skor yang diperoleh sebesar 4.66 skala aiken dengan rata - rata 0.77 skala aiken.

Tabel 3 Skor Uji Validasi Ahli menggunakan Aiken

\begin{tabular}{l|c|c|c|c|c}
\hline \multicolumn{1}{c|}{ Aspek } & $\begin{array}{c}\text { Jumlah } \\
\text { Validator } \\
\text { Peraspek }\end{array}$ & $\begin{array}{c}\text { Jumlah } \\
\text { Kisi }\end{array}$ & $\begin{array}{c}\text { Jumlah } \\
\text { Skor } \\
\text { Validasi }\end{array}$ & $\begin{array}{c}\text { Rata-rata } \\
\text { Skor Vali } \\
\text { dasi }\end{array}$ & Kategori \\
\hline Pedagogik & 2 & 16 & 12.01 & 0,75 & Valid \\
Materi & 2 & 9 & 6,99 & 0,77 & Valid \\
Desain & 2 & 6 & 4,66 & 0,77 & Valid \\
Jumlah & $\mathbf{6}$ & $\mathbf{1 9}$ & $\mathbf{2 3 , 6 6}$ & $\mathbf{0 , 7 6}$ & Valid \\
\hline
\end{tabular}




\section{b. One to One (Uji Coba Perorangan)}

Spesifik prototype juga di evaluasi one to one dengan tujuan menguji kepraktisan modul. $\mathrm{Uji}$ one to one melibatkan 3 orang mahasiswa pendidikan kimia 2017 yang memiliki kriteria berbeda, masing-masing dari mereka ber kemampuan tinggi, sedang dan rendah.Melalui uji one to one didapat beberapa komentar dan saran tentang kelayakan modul untuk diperbaiki lebih lanjut. Uji One to one menggunakan instrumen wawancara terstruktur yang berisi pertanyaan-pertanyaan penilaian berkaitan dengan karakteristik modul yang dikembangkan. Hasil penilaian wawancara terstruktur berupa skor akhir untuk menilai kepraktisan spesifik prototipe.

Tabel 4. Skor Kepraktisan Modul Tahap One to One menggunakan Aiken

\begin{tabular}{|l|c|l|}
\hline \multicolumn{1}{|c|}{ Butir } & $\begin{array}{c}\text { Koefisien Aiken } \\
(\mathrm{V})\end{array}$ & \multicolumn{1}{|c|}{ Keterangan } \\
\hline $\begin{array}{l}\text { Urutan dalam sintak pada Modul Kimia Muatan } \\
\text { Lokal }\end{array}$ & 0,78 & Cukup Praktis \\
\hline Kejelasan tulisan pada Modul. & 0,67 & Cukup Praktis \\
\hline Kejelasan tulisan pada Rencana Program Studi & 0,67 & Praktis \\
\hline $\begin{array}{l}\text { Bahasa yang digunakan pada Rencana Program } \\
\text { Studi dapat dimengerti }\end{array}$ & 0,67 & Praktis \\
\hline Tampilan Modul Kimia Muatan Lokal & 0,78 & Praktis \\
\hline $\begin{array}{l}\text { Prosedur pada teknologi dalam Modul Kimia } \\
\text { Muatan Lokaldapat dimengerti }\end{array}$ & 0,78 & Cukup Praktis \\
\hline Menumbuhkan rasa ingin tahu & 0,89 & Sangat Praktis \\
\hline Pemahaman konsep kimia & 0,67 & Cukup Praktis \\
\hline Memotivasi untuk merespon pembelajaran & 0,78 & Praktis \\
\hline Rata - rata & 0.74 & Praktis \\
\hline
\end{tabular}

\section{c. Small Group (Uji Kelompok Kecil)}

Tahap berikutnya small group (uji kelompok kecil) adalah menguji kepraktisan modul (prototype 1) dalam skala yang lebih besar dibandingkan dengan one to one, hal ini bertujuan agar tingkat kepraktisan lebih diperkuat. Uji small group dilakukan oleh 9 mahasiswa yang memiliki tingkat kemampuan bervariasi yakni tinggi, sedang, dan rendah. Dari uji small group mahasiswa memberikan komentar dan saran untuk lebih menyempurna kan kualitas modul. Modul direvisi berdasarkan saran mahasiswa tersebut.

Hasil revisi modul yang disesuaikan dengan saran-saran siswa pada uji small group merupakan prototype 2. Untuk mengetahui kepraktisan modul prototype 2 ini, selanjutnya dihitung hasil analisis data uji small group yang merupakan penilaian dari instrumen yang disediakan. Rekapitulasi hasil analisis data tersebut dapat dilihat pada Tabel 5 . 
Tabel 5. Rekapitulasi Hasil Analisis Small Group Menggunakan Aiken

\begin{tabular}{|c|c|c|c|c|c|c|c|c|c|c|c|}
\hline \multirow{2}{*}{ Butir } & \multicolumn{9}{|c|}{ Mahasiswa } & \multirow{2}{*}{$\begin{array}{l}\text { Koefis } \\
\text { ien } \\
\text { Aiken } \\
(\mathrm{V})\end{array}$} & \multirow{2}{*}{ Kategori } \\
\hline & AP & SF & $\mathrm{JF}$ & AS & RA & MY & SP & HS & NF & & \\
\hline $\begin{array}{l}\text { Urutan dalam sintak } \\
\text { pada Modul Kimia } \\
\text { Muatan Lokal }\end{array}$ & 4 & 2 & 4 & 3 & 2 & 4 & 4 & 4 & 4 & 0,81 & $\begin{array}{l}\text { Sangat } \\
\text { Praktis }\end{array}$ \\
\hline $\begin{array}{l}\text { Kejelasan tulisan } \\
\text { pada Modul }\end{array}$ & 3 & 2 & 4 & 2 & 2 & 3 & 3 & 4 & 3 & 0,62 & Praktis \\
\hline $\begin{array}{l}\text { Kejelasan tulisan } \\
\text { pada Rencana Prog } \\
\text { ram Studi }\end{array}$ & 4 & 3 & 3 & 3 & 3 & 3 & 4 & 4 & 4 & 0,81 & $\begin{array}{l}\text { Sangat } \\
\text { Praktis }\end{array}$ \\
\hline $\begin{array}{l}\text { Bahasa yang } \\
\text { digunakan pada } \\
\text { Rencana Program } \\
\text { Studi dapat } \\
\text { dimengerti }\end{array}$ & 3 & 4 & 4 & 1 & 4 & 4 & 4 & 3 & 4 & 0,81 & $\begin{array}{l}\text { Sangat } \\
\text { Praktis }\end{array}$ \\
\hline $\begin{array}{l}\text { Tampilan Modul } \\
\text { Kimia Muatan } \\
\text { Lokal }\end{array}$ & 4 & 3 & 4 & 3 & 3 & 3 & 4 & 3 & 4 & 0,81 & $\begin{array}{l}\text { Sangat } \\
\text { Praktis }\end{array}$ \\
\hline $\begin{array}{l}\text { Prosedur pada } \\
\text { teknologi dalam } \\
\text { Modul Kimia } \\
\text { Muatan Lokal dapat } \\
\text { dimengerti }\end{array}$ & 3 & 2 & 4 & 1 & 2 & 4 & 3 & 2 & 4 & 0,62 & Praktis \\
\hline $\begin{array}{l}\text { Menumbuhkan rasa } \\
\text { ingin tahu }\end{array}$ & 3 & 4 & 4 & 4 & 3 & 3 & 4 & 3 & 3 & 0,78 & Praktis \\
\hline $\begin{array}{l}\text { Pemahaman konsep } \\
\text { kimia }\end{array}$ & 3 & 3 & 4 & 2 & 2 & 3 & 3 & 3 & 4 & 0,67 & Praktis \\
\hline $\begin{array}{l}\text { Memotivasi untuk } \\
\text { merespon } \\
\text { pembelajaran }\end{array}$ & 3 & 4 & 4 & 4 & 3 & 3 & 4 & 3 & 4 & 0,85 & $\begin{array}{l}\text { Sangat } \\
\text { Praktis }\end{array}$ \\
\hline Rata - rata & & & & & & & & & & 0,75 & Praktis \\
\hline
\end{tabular}

\section{KESIMPULAN}

Berdasarkan hasil penelitian, dapat disimpulkan bahwa Modul Kimia Muatan Lokal Terintegrasi STEM Problem Based Learning telah valid praktis. Modul Kimia Muatan Lokal Terintegrasi STEM Problem Based Learning dinyatakan valid setelah melalui penilaian dari tiga validator, validasi pedagogik 0,75 skala aiken (valid), validasi materi 0,77 skala aiken (valid), dan validasi desain 0,77 skala aiken (valid). Sedangkan kepraktisan modul dilihat dari hasil wawancara terstruktur pada proses one to one dan small group. Pada tahap one to one di dapat nilai sebesar 0,74 skala aiken (praktis) dan pada tahap small group didapat nilai sebesar 0,75 skala Aiken yang berarti praktis. Berdasarkan nilai tersebut Modul Kimia Muatan Lokal Terintegrasi STEM Problem Based Learning

\section{DAFTAR PUSTAKA}

Ali, R., Ghazi, S. R., Khan, M. S., Hussain, S.,\& Faitma, Z. T. (2010). Effectiveness of Modular Teaching in Biology at Secondary Level. Asian

Social Science, 49-54. 
Kordi, G. (2005). Budidaya Ikan Patin Biologi, Pembenihan dan Pembesaran. Yogyakarta: Yayasan Pustaka Nusatama

Parmin \& E. Peniati. (2012). Pengembangan Modul Mata Kuliah Strategi Belajar Mengajar IPA Berbasis Hasil Penelitian Pembelajaran. Jurnal Pendidikan IPA Indonesia. 1 (1): 8-15.

Permendiknas. (2014). Permendikbud no.59 tahun 2014 tentang kurikulum SMA/MA. Jakarta: Kementrian Pendidikan dan Kebudayaan.

Pratiwi, Yussi., Tri Redjeki, \& Mohammad Masyukri. (2014). Pelaksanaan Model
Pembelajaran Problem Based Learning (PBL) pada Materi Redoks Kelas X SMA Negeri 5 Surakarta Tahun Pelajaran 2013/2014. Jurnal Pendidikan Kimia (JPK), 3 (3): 40-48.

Santoso, Djoko. (2013). Modul Pembelajaran Kewirausahaan. Jakarta: Direktorat Jenderal Pembelajaran dan Kemahasiswaan Ditjen Pendidikan Tinggi Kementerian Pendidikan dan Kebudayaan Susanto, H dan Amri K. (2002). Budidaya Ikan Patin. Jakarta: Penebar Swadaya. 